\title{
THE EFFECT OF CADMIUM CHLORIDE ON THE BLOOD-TESTIS BARRIER OF THE GUINEA-PIG
}

\author{
M. H. JOHNSON \\ Department of Physiology, Downing Street, Cambridge
}

(Received 30th January 1969)

Cadmium exerts a selective toxic effect on the blood vessels of the testis and caput epididymidis (Gunn, Gould \& Anderson, 1963; Chiquoine, 1964; Mason \& Young, 1967) and investigations into the changes in blood flow and vascular permeability suggest that the primary site of action is the end-arterial bed (Niemi \& Kormano, 1965; Waites \& Setchell, 1966; Glegg \& Carr, 1966; Gupta, Barnes \& Skelton, 1967). The resulting ischaemia and interstitial oedema then cause failure of spermatogenesis (Mason \& Young, 1967).

Dye studies suggest that a barrier exists at the tubular as well as the vascular level (Kormano, 1967a, b), and the presence of this barrier is essential for the production of a testicular fluid differing in composition from serum (Setchell, 1967; Setchell, Dawson \& White, 1968; Johnson \& Setchell, 1968). The present study shows that, in the untreated guinea-pig as in the rat, subcutaneously administered acriflavine produces weak staining of interstitial nuclei and cannot penetrate the tubular barrier but that, following $\mathbf{C d C l}_{2}$ administration, staining of all parts of the testis occurs.

Guinea-pigs, weighing 500 to $600 \mathrm{~g}$, were injected subcutaneously with a $2 \% \mathrm{CdCl}_{2}$ solution $(10 \mathrm{mg} / \mathrm{kg})$. Groups of animals were given a subcutaneous injection of $2 \%$ acriflavine solution $(20 \mathrm{mg} / \mathrm{kg})$ at a different site after $0,7,19$, 31 or $43 \mathrm{hr}$, and $5 \mathrm{hr}$ later were killed and the testes removed. Blocks were snap frozen, and freeze-dried sections were prepared and examined on the Zeiss photomicroscope. Positive controls consisted of testes from animals which had been immunized with homologous testis, and injected with acriflavine $5 \mathrm{hr}$ before killing (Pl. 1, Fig. 1) (tubular permeability to acriflavine rises during the initial stages of the resulting testicular damage-Johnson, unpublished data), and a testis from a 2-day-old guinea-pig injected with acriflavine (Pl. 1, Fig. 2) (the tubular barrier is not fully developed at this age). Negative controls consisted of a testis from an animal which was injected with $\mathrm{CdCl}_{2}$ but not acriflavine (see Pl. 1, Fig. 3 and line 6 in Table 1) and a testis from an animal injected with acriflavine only (see line 1 in Table 1). The results in the cadmium chloride-treated animals are summarized in Table 1. The staining of interstitial nuclei is shown in Pl. 1, Fig. 4 and of interstitial and degenerating intratubular nuclei in Pl. 1, Fig. 5.

Staining of interstitial nuclei became stronger within $12 \mathrm{hr}$ of cadmium administration, suggesting an increased vascular permeability. After $24 \mathrm{hr}$, there was a focal breakdown of the tubular barrier but by $48 \mathrm{hr}$ the whole 
testis was involved. Phase-fluorescence examination of the freeze-dried sections revealed that all obviously damaged tubules contained fluorescent nuclei. The intensity of fluorescence was not correlated with the degree of damage but probably varied with the proximity of blood vessels. Some apparently normal tubules were also stained and this suggested that breakdown of the barrier occurred early in the production of damage. Other normal tubules in partially damaged testes were not stained.

TABLE 1

THE EFFECT OF $\mathrm{CdCl}_{2}$ ON THE ACRIFLAVINE STAINING PATTERN OF THE GUINEA-PIG TESTIS

\begin{tabular}{|c|c|c|c|c|c|}
\hline $\begin{array}{l}\text { Time after } \mathrm{CdCl}_{2} \\
\text { injection }(h r)\end{array}$ & $\begin{array}{l}\text { No. of testes } \\
\text { examined }\end{array}$ & $\begin{array}{l}\text { Vascular } \\
\text { staining }\end{array}$ & $\begin{array}{l}\text { Interstitial } \\
\text { staining }\end{array}$ & $\begin{array}{l}\text { Intratubular } \\
\text { staining }\end{array}$ & Histology \\
\hline $\begin{array}{c}0 \\
\text { (negative control- } \\
\text { acriflavine only) }\end{array}$ & 10 & ++ & - to + & - & Normal \\
\hline 5 & 4 & ++ & \pm to + & - & Normal \\
\hline 12 & 10 & ++ & ++ & - & $\begin{array}{l}\text { Interstitial oedema; } \\
\text { very few sites of } \\
\text { focal damage }\end{array}$ \\
\hline 24 & 12 & ++ & ++ & $-1 \pm 1+$ & $\begin{array}{l}\text { Interstitial oedema; } \\
\text { areas with necrosing } \\
\text { tubules and pycnotic } \\
\text { nuclei }\end{array}$ \\
\hline 36 & 12 & ++ & ++ & $\begin{array}{c}-1 \pm 1+1 \\
++\end{array}$ & $\begin{array}{l}\text { Interstitial oedema; } \\
\text { areas with necrosing } \\
\text { tubules and pycnotic } \\
\text { nuclei }\end{array}$ \\
\hline $\begin{array}{c}36 \\
\text { (negative control- } \\
\text { CdCl }_{2} \text { only) }\end{array}$ & 2 & - & - & - & $\begin{array}{l}\text { Interstitial oedema; } \\
\text { areas with necrosing } \\
\text { tubules and pycnotic } \\
\text { nuclei }\end{array}$ \\
\hline 48 & 4 & ++ & ++ & ++ & $\begin{array}{l}\text { Complete } \\
\text { degeneration }\end{array}$ \\
\hline
\end{tabular}

Damage within the tubules is usually regarded as due to a direct effect of ischaemia on spermatogenesis. However, experimental ischaemia of the perfused testis causes an almost immediate cessation in the flow of rete testis. fluid (Linzell \& Setchell, 1968) and the production of this fluid is presumably closely linked with the selective exclusion by the blood-testis barrier of serum. components. This suggests a new explanation for the damage caused by $\mathrm{CdCl}_{2}$. The tubular barrier could be the primary site of action of the ischaemia produced by the administration of $\mathrm{CdCl}_{2}$, and after the break-

\section{PLATE 1}

Acriflavine fluorescence in guinea-pig testes.

FIG. 1. Positive control testis following immunization by homologous testis antigen.

Fig. 2. Positive control testis from 2-day-old animal.

Fic. 3. Negative control testis of animal treated with cadmium chloride but not with acriflavine.

FIG. 4. Testis of cadmium chloride-treated animal showing staining of interstitial nuclei.

Fic. 5. Testis of cadmium chloride-treated animal showing staining of interstitial and degenerating intratubular nuclei. 
1'.111\%

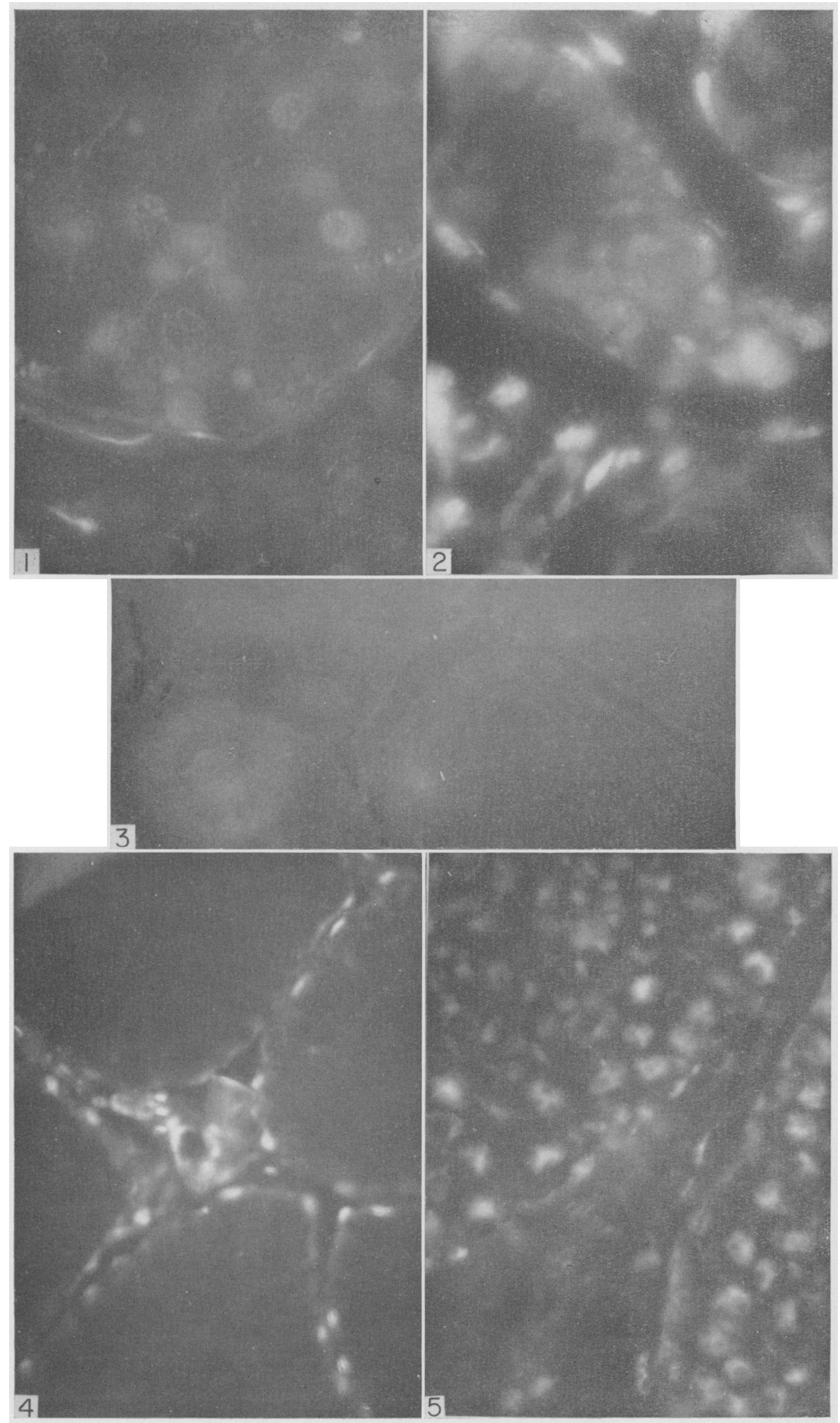

fungth ji! 
down of this barrier, the influx of serum components might secondarily initiate the damage to tubule contents. This secondary damage could be due to a specific cytotoxic action against germinal cells caused by the presence of a natural antibody (Spooner, 1964; Johnson, 1968), to cadmium interference with zinc metabolism in the tubule (Pařizek 1960) or to non-specific changes in the micro-environment of the cells.

The author is indebted to the M.R.G. for a research scholarship, and to the Ford Foundation for providing equipment.

\section{REFERENCES}

GHiQuorne, A. D. (1964) Observations on the early events of cadmium necrosis of the testis. Anat. Rec. 149, 23.

Clegg, E. J. \& CARR, I. (1966) Increased vascular permeability in the reproductive organs of cadmium chloride treated male rats. $\mathcal{F}$. Anat. 100, 696 .

Gunn, S. A., Gould, T. C. \& ANDERson, W. A. D. (1963) The selective injurious response of testicular and epididymal blood vessels to cadmium and its prevention by zinc. Am. F. Path. 42, 685 .

Gupta, R. K., Barnes, G. W. \& Skelton, F. R. (1967) Light microscopic and immunopathologic observations on cadmium chloride induced injury in mature rat testis. Am. F. Path. 51, 191.

JoHnson, M. H. (1968) The characterization of a natural antibody in normal guinea-pig serum reacting with homologous spermatozoa. F. Reprod. Fert. 17, 403.

Johnson, M. H. \& SeTchell, B. P. (1968) The protein and immunoglobulin content of rete testis fluid of rams. J. Reprod. Fert. 16, 503.

Kormano, M. (1967a) Dye permeability and alkaline phosphatase activity of testicular capillaries in the postnatal rat. Histochemie, 9, 327.

Kormano, M. (1967b) Distribution of injected L-3,4-dihydroxyphenylalanine (L-Dopa) in the adult rat testis and epididymis. Acta physiol. scand. 71, 125.

Linzell, J. L. \& Setcheld, B. P. (1968) The output of spermatozoa and fluid by, and the metabolism of, the isolated perfused testis of the ram. F. Physiol., Lond. 195, 25P.

Mason, K. E. \& Young, J. O. (1967) Effects of cadmium upon the excurrent duct system of the rat testis. Anat. Rec. 159, 311.

NiEm, M. \& Kormano, M. (1965) An angiographic study of cadmium-induced vascular lesions in the testis and epididymis of the rat. Acta path. microbiol. scand. 63, 513 .

PAǨ́zé, J. (1960) Sterilization of the male by cadmium salts. F. Reprod. Fert. 1, 1036.

Setchell, B. P. (1967) The blood testicular barrier in sheep. 7. Physiol., Lond. 189, 63p.

Setcheld, B. P., Dawson, R. M. C. \& White, R. W. (1968) The high concentration of free myoinositol in rete testis fluid from rams. F. Reprod. Fert. 17, 219.

SPOoner, R. L. (1964) Cytolytic activity of the serum of normal male guinea-pigs against their own testicular cells. Nature, Lond. 202, 915.

Waites, G. M. H. \& Setchell, B. P. (1966) Changes in blood flow and vascular permeability of the testis, epididymis and accessory reproductive organs of the rat after administration of cadmium chloride. F. Endocr. 34, 329. 